\title{
FACTORS INFLUENCING PURCHASE INTENTION USING PEER- TO-PEER SOCIAL MEDIA PLATFORM ONLINE SHOPPING
}

\author{
Detha Eliza $^{1}$, Wing Wahyu Winarno ${ }^{2}$, Hendrik ${ }^{1}$ \\ ${ }^{1}$ Universitas Islam Indonesia, ${ }^{1} \mathrm{Jl}$. Kaliurang Km.14,5, Besi, Umbulmartani \\ ${ }^{2}$ Sekolah Tinggi Ilmu Ekonomi YKPN, Jl. Seturan Raya, Kledokan, Caturtunggal \\ Email : ${ }^{1} 16917205 @$ students.uii.ac.id
}

\begin{abstract}
Online trading transactions are now widely used by business people, one of which is e-commerce Peer-to-Peer through online stores. With online stores, consumers don't have to bother going to conventional stores to get goods. But shopping using online stores has risks including fraud-prone, products that have been ordered and paid for are not shipped and the quality of the product is not the same. Although there are many problems that cause losses experienced by consumers, but in reality it does not discourage consumers to keep shopping online. The aim of the researcher is to analyze the factors that influence purchase intentions using the Peer-to-Peer social media platform in online shopping. This research uses quantitative methods and data analysis using Structural-Equation-Modeling with PartialLeast-Square software. With a sample of 100 people, it was concluded that economic benefits and sustainable purchases are determinants of consumer satisfaction and purchase intentions. This study concludes that customer intentions and satisfaction in the context of online accommodation and transportation can be generalized in the context of Peer-to-Peer online shopping despite differences in findings.
\end{abstract}

Keywords: Buy Intention; Peer-to-Peer; Social Media, Online Shopping

\section{Pendahuluan}

Semakin tingginya persaingan dalam sektor bisnis di era modern seperti saat ini, mengharuskan produsen dalam sebuah sektor industry untuk dapat bersaing memberikan peranan positif bagi keberadaan bisnis mereka di masa depan. Industry pada sektor perdaganganpun mengalami peningkatan seiring dengan kemajuan teknologi internet yang berperan meningkatkan proses jual beli dalam sektor perdagangan. Berdasarkan hasil survei yang dilakukan Asosiasi Penyelenggara Jasa Internet Indonesia (APJII) dan Polling Indonesia, pengguna internet di Indonesia pada tahun 2016 jumlahnya mencapai 132,7 juta, pada tahun 2017 jumlahnya 143,26 juta dan pada tahun 2018 jumlahnya 171,18 juta jiwa. Bank Indonesia yang dikutip dari berita situs daring Kompas.com, menyatakan bahwa jumlah pembelian secara daring setiap tahun terus meningkat di Indonesia. Di tahun 2016 jumlah pembelian secara daring diperkirakan mencapai 9,6\% , pada tahun 2017 sebanyak 10,7\% dan pada tahun2018 mencapai $11,9 \%$ dari total populasi di Indonesia.

Bertambahnya pelaku bisnis yang melakukan promosi, penjualan (selling), pembelian (buying), dan pemasaran (marketing) melalui dunia digital seperti jasa internet sering dikenal dengan istilah perdagangan elektronik (e-commerce) [1]. Menurut [2] e-commerce terbagi menjadi 5 macam model bisnis yaitu: Bisnis ke Pelanggan atau Business-to-Consumer (B2C), bisnis ke bisnis atau Business to Business (B2B), konsumen ke konsumen atau Consumer-toConsumer (C2C), Peer-to-Peer (P2P), Perdagangan melalui selular atau Mobile Commerce (M-commerce).

Pada awalnya proses pemasaran suatu produk dilakukan melalui pemasaran tradisional atau konvensional (offline). Namun sekarang dengan menggunakan media daring konsumen dipermudah dalam melakukan transaksi jual beli barang melalui situs belanja 
daring sehingga konsumen tidak perlu datang langsung ke toko untuk melakukan transaksi jual beli, konsumen cuma perlu membuka aplikasi melalui handphone dan menetapkan barang atau jasa yang mereka inginkan. Platform yang terus berkembang memungkinkan koordinasi sumber daya dan pertukaran diantara masing-masing individu atau biasa disebut Peer-to-Peer [3]. Peer-to-Peer adalah salah satu bentuk e-commerce yang banyak digunakan oleh masyarakat di Indonesia. Platform bisnis Peer-to-Peer (P2P) merupakan model bisnis daring di mana tempat pembeli dan penjual bertukar produk dan layanan tanpa mengeluarkan biya dalam penggunaan aplikasi. Model bisnis yang menerapkan bentuk Peer-to-Peer adalah platform media sosial.

Berbelanja secara daring melalui platform media sosial toko daring (online shop), saat ini mulai menjadi salah salah satu aktivitas populer di internet dan jumlahnya terus meningkat [4]. Menurut [5] "keunggulan toko daring dibandingkan toko konvensional (offline) yaitu toko daring dibuka 24 jam, dapat diakses di mana saja, konsumen dapat menghabiskan waktu bermain media sosial sembari mencari dan melihat katalog produk dengan mudah tanpa harus membuka aplikasi ecommerce lagi”. Menurut [6] kelebihan belanja daring adalah: 1) menghemat biaya, 2) Barang bisa langsung diantar ke rumah. 3) Pembayaran dilakukan secara transfer, dan 4) Harga lebih bersaing. Namun selain kelebihan berbelanja secara daring melalui platform media sosial juga memiliki kekurangan yaitu rawan penipuan, produk yang telah dipesan dan dibayar tidak dikirim, dan kualitas produk tidak sama dengan deskripsi produk yang ditampilkan pada halaman penjualan. Walaupun banyak permasalahan yang menimbulkan kerugian yang dialami konsumen muncul namun pada kenyataannya hal tersebut tidak mengurungkan niat para konsumen untuk tetap melakukan belanja melalui transaksi daring.

Penelitian yang dilakukan We Are Social menyatakan bahwa platform media sosial Peer-to-Peer yang paling aktif dan banyak dikunjungi di Indonesia adalah Youtube sebesar 49\%, Facebook sebesar 48\% dan Instagram sebesar 39\%. Hal ini dimanfaatkan produsen sebagai media penjualan yang dalam proses jual belinya dapat menarik perhatian para konsumen. Salah satu alasan konsumen tidak berbelanja daring karena kurangnya rasa percaya konsumen terhadap penjual [7]. Dalam bisnis daring kepercayaan sangat penting dalam menjaga hubungan jangka panjang antara produsen dan konsumen karena belanja daring sangat beresiko,sehingga kepercayaan memainkan peran yang penting dalam mempengaruhi transaksi daring [8] [9].

Para produsen terkadang menjual produk yang sama seperti produk asli namun saat produk diterima oleh konsumen produk tidak sama dengan yang ditampilakan di toko daring produsen. Hal ini terjadi karena adanya efisiensi jarak yang dihadirkan internet yang menimbulkan keterbatasan konsumen dalam memeriksa kualitas produk, konsumen hanya bisa melihat melalui gambar yang diposting oleh produsen di toko daring dan tidak secara langsung menyentuh maupun merasakan produk. Saat toko daring dapat dipercaya maka hal ini dapat memunculkan minat beli konsumen.

Minat beli konsumen mencerminkan keinginan hati konsumen untuk membeli sesuatu produk, ketika konsumen merasakan kepuasan akan kualitas produk dan jasa maka niat belanja konsumen pun akan semakin besar. Kepuasan sendiri merupakan perasaan senang maupun kecewa konsumen yang timbul karena membandingkan kemampuan yang dipersepsikan dengan kinerja sesungguhnya dari suatu produk [10]. Kepuasan konsumen dalam berbelanja daring secara positif dan signifikan akan naik apabila penjual daring mempunyai sifat jujur serta meberikan informasi yang lengkap pada setiap produk yang dijual, sehigga kepercayaan konsumen yang lebih tinggi [11].

Banyaknya macam dan merek suatu produk yang ditawarkan oleh toko daring (online shop) akan memberikan pengalaman menyenangkan dan membangkitkan keinginan belanja konsumen saat mencari produk yang diinginkan [12]. Kenikmatan (enjoyment) dalam 
pembelian mempengaruhi psikolgis konsumen yang mendukung konsumen untuk berbelanja di toko daring (online shop). Kenikmatan belanja adalah perasan senang yang dirasakan konsumen dari aktifitas yang dilakukan saat berbelanja daring [13]. Menurut [14] pembelian dan pengalaman di masa lalu konsumen akan menentukan keinginan konsumen dalam melakukan kelanjutan dalam pembelian kembali pada toko daring. Menurut [15] kelanjutan merupakan suatu proses yang mencakup empat komponen yang saling terhubung yaitu ekologi, ekonomi, politik dan budaya. Berbelanja daring melalui Peer-to-Peer platform media sosial daring menghasilkan pengalaman yang menjadi faktor motivasi konsumen [16].

Manfaat ekonomi dalam konsumsi diperoleh melalui penghematan terhadap pengeluaran karena biaya yang lebih rendah bahkan tanpa biaya sama sekali serta kemudahan akses yang disediakan oleh konsumsi kolaboratif yang membuat penggunanya dapat menghemat waktu dan melakukan efisiensi [17]. Selain manfaat ekonomi konsumen juga dapat merasakan manfaat lainnya yaitu manfaat sosial. Beberapa manfaat sosial yang diperoleh dari aktivitas sharing antara lain ketika budaya partisipasi dapat menciptakan suatu kegembiraan, apresiasi atau penghargaan, kepuasan serta kepercayaan diri [18] [19].

Studi literatur yang membahas faktor penentu niat menggunakan layanan Peer-toPeer telah diteliti misalnya [17] yang menemukan faktor kelanjutan niat, kenikmatan, dan manfaat ekonomi untuk mempengaruhi niat konsumen untuk ikut serta dalam platform Peerto-Peer. Efek dari penghematan biaya, milik masyarakat, keakraban, kepercayaan, dan utilitas, pada kepuasan dan niat beli konsumen di masa akan datang menggunakan layanan Peer-to-Peer [20]. Penelitian [21] mengoperasionalkan motivasi ini (penghargaan intrinsik dan ekstrinsik) menjadi manfaat sosial, kenikmatan, manfaat ekonomi, manfaat lokasi, kelanjutan, dan fasilitas dalam layanan Peer-to-Peer Accommodation. Pada penelitian [22], mereplikasi dari penelitian [21], dengan variable yaitu kenikmatan, manfaat sosial, manfaat ekonomi, kelanjutan, kepuasan, dan niat beli namun pada konteks transportasi daring Peer-toPeer peneliti menghapus manfaat dan fasilitas lokasi. Banyak penelitian yang membahas mengenai bisnis mobile-commerce (m-ecommerce) menggunakan media sosial Instagram, Facebook, Twiter, Youtube, Line maupun media sosial lainnya. Sehingga membuat penulis tertarik untuk melakukan penelitian mengenai faktor-faktor yang mempengaruhi niat beli konsumen pada Peer-to-Peer platform media sosial, dengan mengadaptasi dan mengembangkan model-model penelitian terdahulu.

\section{Metode}

\subsection{Variabel Penelitian}

Pada penelitian ini digunakan dua jenis variabel, yaitu variabel laten eksogen dan dependen. Variabel laten eksogen yaitu variabel independen yang mempengaruhi dependen ditunjukkan dengan anak panah yang menuju variabel laten endogen. Variabel eksogen dalam penelitian ini yaitu Kepercayaan (KP1), Manfaat Sosial (MS1), Manfaat Ekonomi (ME1), Kenikmatan (KN1), Kelanjutan pembelian (KL1). Sebaliknya variabel endogen yaitu variabel dependen yang dipengaruhi variabel independen yang ditunjukkan oleh anak panah yang menuju variabel tersebut. Pada penelitian ini variabelendogen yaitu kepuasan (KPS1) dan Niat Beli (NB1).

\subsection{Penentuan Sampel}

Pada penelitian ini menggunakan teknik sampling purposive, yaitu teknik pengambilan sampel sumber data dengan pertimbangan tertentu [23]. Teknik dipilih oleh peneliti karena dalam penelitian yang dilakukan peneliti memiliki karakteristik dalam memilih responden, sampel yang digunakan harus memenuhi kriteria sebagai berikut: (1) Mahasiswa yang mempunyai akun Facebook dan Instagram, (2) Mahasiswa yang pernah berbelanja melalui Facebook dan Instagram sampai dengan barang datang. 
Untuk menentukan banyak sampel yang diperlukan, maka penelitian ini menggunakan rumus yang dikembangkan oleh [24].

Ukuran Sampel Minimum

$=$ jumlah indikator $\mathrm{x} 5$

Ukuran Sampel Minimum

$=20 \times 5$

$=100$

Dari rumusan di atas disimpulkan bahwa minimum sampel yang akan digunakan adalah 100 orang responden dari mahasiswa Universitas Islam Indonesia yang pernah berbelanja daring melalui media sosial Facebook dan Instagram.

\subsection{Metode Analisis Data}

Pada penelitian ini metode yang digunakan adalah metode kuantitatif. Pengumpula data dalam penelitian yang dilakukan dengan cara kuesioner yang didistribusikan secara daring (google form) dan studi pustaka yang dilakukan dengan menentukan informasi, asal sumber informasi. Pengolahan statistik untuk menguji kebenaran hipotesis penelitian dengan bantuan Structural Equation Modeling dengan menggunakan software SmartPLS3.0. Penelitian ini menggunakan skala Likert tipe lima sebagai syarat model luar dari PLS. Alat analisis yang digunakan untuk menguji hipotesis terdiri dari uji outer model, dan inner model.

Analisis uji yang dilakukan pada outer model akan did dari pengaruh yaitu uji validitas dan uji reliabilitas. Menurut [25] menyatakan "uji validitas digunakan untuk mengukur sah, atau valid tidaknya suatu kuesioner." Ada dua macam evaluasi yang dilakukan pada uji validitas yaitu: Convergent Validity, Discriminant Validity. Menurut [26] "uji reliabilitas yang diukur dengan dua kriteria yaitu dengan composite reliability dan cronbach's alpha dari blok yang mengukur konstruk". Analisis uji yang selanjutnya adalah uji inner model dengan evaluasi yang dilakukan untuk pengujian determinasi atau analisis Varians $\left(\mathrm{r}^{2}\right)$ dan nilai $\mathrm{t}-$ statistik dari pengujian koefisien jalur (path coefficient) yang merupakan uji good-fit model. Koefisien determinasi (R2) "merupakan pengukuran seberapa jauh kemampuan model dalam menerangkan variasi variabel dependen" [27]. Menurut [27]"Uji-t digunakan untuk menunjukkan seberapa jauh pengaruh satu variabel independen secara individual dalam menerangkan variabel dependen".

\section{Hasil dan Pembahasan}

\subsection{Karakteristik Responden}

Karakteristik dari responden yang dikumpulkan untuk mengetahui profil dari responden penelitian. Berdasarkan hasil penelitian yang dilakukan peneliti terhadap mahasiswa Universitas Islam Indonesia, dapat diketahui gambaran mengenai karakteristik responden berdasarkan tiga aspek yaitu jenis kelamin, media sosial yang digunakan dan fakultas dari responden.

Tabel 1. Karakteristik Resonden

\begin{tabular}{|c|c|c|c|c|}
\hline No & Aspek & Klasifikasi & Jumlah & Presentase (\%) \\
\hline \multirow[t]{2}{*}{1.} & \multirow[t]{2}{*}{ Jenis Kelamin } & Laki-laki & & $33 \%$ \\
\hline & & Perempuan & & $67 \%$ \\
\hline \multicolumn{3}{|c|}{ Jumlah } & 100 Orang & $100 \%$ \\
\hline \multirow{3}{*}{2} & \multirow{3}{*}{$\begin{array}{l}\text { Media Sosial yang digunakan dalam } \\
\text { belanja online }\end{array}$} & Facebook & 13 & $13 \%$ \\
\hline & & Instagram & 71 & $71 \%$ \\
\hline & & Keduanya & 16 & $16 \%$ \\
\hline \multicolumn{3}{|c|}{ Jumlah } & 100 & $100 \%$ \\
\hline \multirow{4}{*}{3} & \multirow{4}{*}{ Fakultas } & FTI & 48 & $48 \%$ \\
\hline & & FTSP & 4 & $4 \%$ \\
\hline & & FMIPA & 22 & $22 \%$ \\
\hline & & Pendidikan Dokter & 2 & $2 \%$ \\
\hline
\end{tabular}




\begin{tabular}{|l|l|l|c|c|}
\hline & & FIAI & 15 & $15 \%$ \\
\cline { 3 - 5 } & & FPSB & 9 & $9 \%$ \\
\hline \multicolumn{2}{|l|}{ Jumlah } & 100 Orang & $100 \%$ \\
\hline
\end{tabular}

Tabel 1 menunjukkan bahwa jumlah responden sebanyak 67 orang jenis kelamin perempuan sedangkan 33 orang jenis kelamin laki-laki. Pada penelitian ini lebih didominasi oleh perempuan hal ini terjadi karena gaya hidup perempuan yang harus mengikuti perkembangan zaman agar lebih up to date.

Pada faktor media sosial yang digunakan dalam berbelanja daring menunjukkan bahwa 71 orang responden memilih Instagram, Facebook sebanyak 13 orang responden dan 16 orang responden menjawab pernah melakukan belanja daring menggunakan keduanya (Facebook dan Instagram). Pada penelitian ini menunjukkan Instagram menjadi media sosial yang banyak digemari mahasiswa dalam berbelanja secara daring di Instagram.

Berdasarkan fakultas dari responden terdapat 6 klasifikasi yaitu FTI sebesar 48 orang, FMIPA sebesar 22 orang responden, FIAI sebesar 15 orang, FPSB sebesar 9 orang, FTSP sebanyak 4 orang responden dan yang terakhir Pendidikan Dokter sebanyak 2 orang. Dari penelitian yang dilakukan responden terbesar adalah Fakultas Teknik Industri (FTI).

\subsection{Pengujian Outer Model}

\section{A. Convergent Validity}

Convergent validity dari measurement model dengan indikator refleksi dapat dilihat dari korelasi antar score idikator dengan score konstruknya. Indikator dapat dikatakan valid apabila indikator > 0,7 namun pada penelitian ini peneliti menggunakan 0,6 agar indikator dikatakan valid. Untuk melihat hasil dari pengujian outer model dengan convergent validity dapat dilihat pada Gambar1.

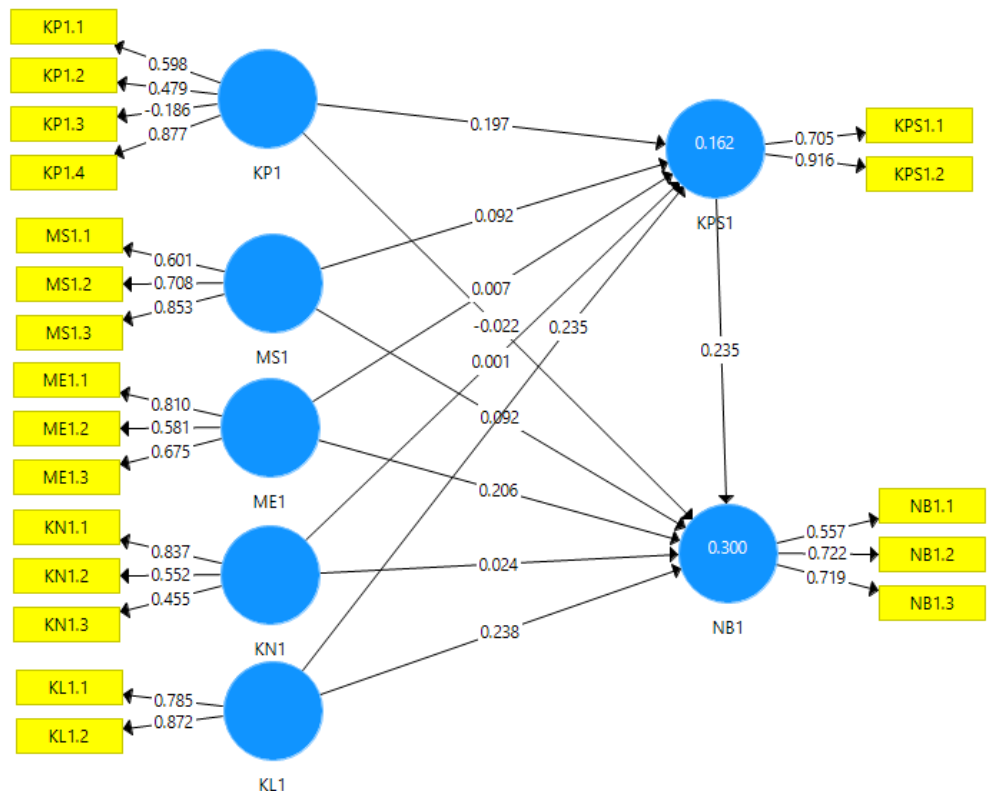

Gambar 1. Gambar hasil uji outer model sebelum uji indikator

Dari gambar 1. dapat dilihat hasil nilai skor dari outer model pada convergen validity sebelum diuji. Hasilnya menunjukkan KP1.1, KP1.2, KP1.3, ME1.2, KN1.1, KN1.3 dan NB1.1 merupakan indikator tidak valid karena memiliki score $<0,6$. Setelah indikatorindikator yang tidak signifikan dihapus maka hasilnya dapat dilihat pada gambar 2 . 


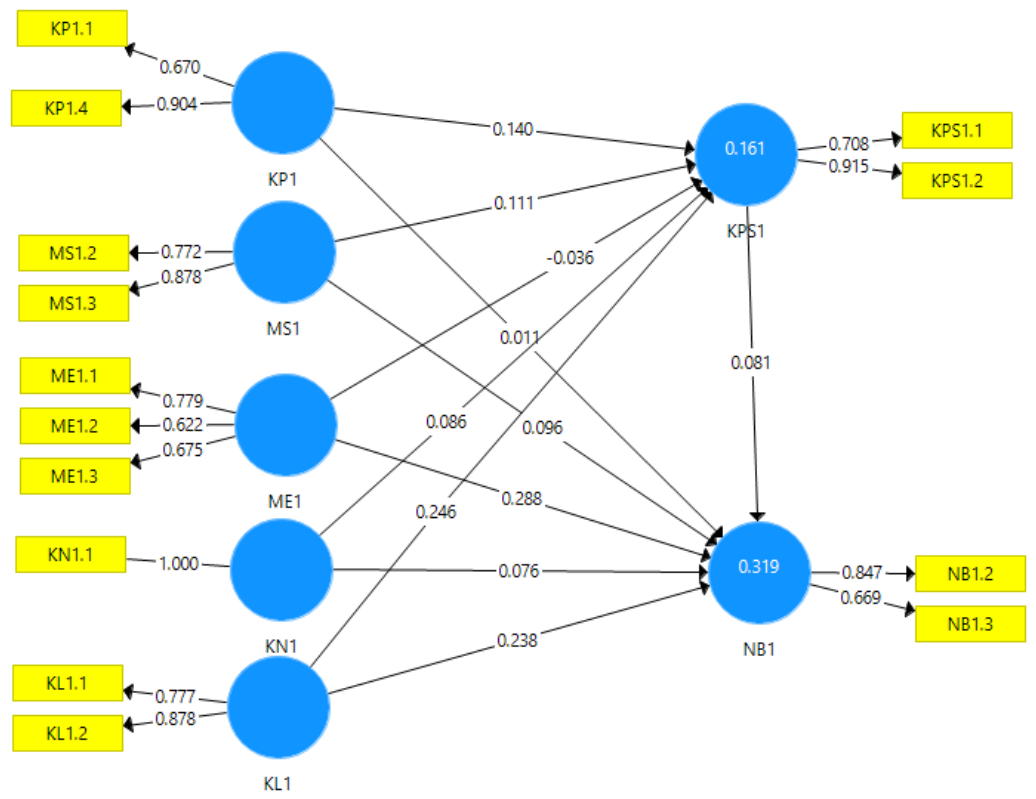

Gambar 2. Gambar hasil uji outer model setelah uji indikator

Pada gambar 2 merupakan hasil kalkulasi model SEM PLS setelah indikator-indikator pada setiap variabel yang tidak memenuhi syarat nilai loading factor dihapuskan, pada gambar dapat dilihat nilai loading factor pada indikator KP1.1, KP1.4, KPS1.1, KPS1.22, MS1.2, MS1.3, ME1M1, ME1.2, ME1.3, KN1.1, KL1.1, KL1.2, NB1.2, dan NB1.3 hasil valid. Hal ini berarti bahwa indikator-indikator memiliki tingkat validitas yang tinggi dan memenuhi syarat convergent validity.

\section{B. Discriminant Validity}

Tabel 1. menunjukkan hasil validitas diskriminan dari model penelitian dengan melihat nilai cross loading-nya.

\begin{tabular}{|l|r|r|r|r|r|r|r|r|r|l|}
\hline & KL1 & KN1 & KP1 & KPS1 & ME1 & MS1 & NB1 & AVE & $\begin{array}{c}\text { Kriteria } \\
\text { (Korelasi } \\
\text { antar } \\
\text { Konstruk } \\
\text { AVE) }\end{array}$ & Status \\
\hline $\begin{array}{l}\text { Kelanjutan } \\
\text { Pembelian }\end{array}$ & $\mathbf{0 , 8 2 2}$ & & & & & & & 0,687 & $0,822>0,687$ & Valid \\
\hline Kenikmatan & 0,335 & $\mathbf{1}$ & & & & & & 1 & $1,00>1,00$ & Valid \\
\hline Kepercayaan & 0,326 & 0,37 & $\mathbf{0 , 7 9 5}$ & & & & & 0,633 & $0,795>0,633$ & Valid \\
\hline Kepuasan & 0,34 & 0,244 & 0,269 & $\mathbf{0 , 8 1 8}$ & & & & 0,669 & $0,818>669$ & Valid \\
\hline M. Ekonomi & 0,348 & 0,438 & 0,206 & 0,173 & $\mathbf{0 , 6 9 5}$ & & & 0,484 & $0,695>0,484$ & Valid \\
\hline M.Sosial & 0,282 & 0,357 & 0,212 & 0,223 & 0,507 & $\mathbf{0 , 8 2 7}$ & & 0,684 & $0,827>0,684$ & Valid \\
\hline Niat Beli & 0,422 & 0,34 & 0,219 & 0,255 & 0,469 & 0,357 & $\mathbf{0 , 7 6 3}$ & 0,582 & $0,763>0582$ & Valid \\
\hline
\end{tabular}

Dari hasil tabel 2. diperoleh hasil akar AVE pada semua konstrak yaitu kepercayaan 0,795 sebesar $(\sqrt{0,633})$, manfaat sosial 0,827 sebesar $(\sqrt{0,684})$, manfaat ekonomi 0,695 sebesar $(\sqrt{0,484})$, kelanjutan pembelian sebesar $0,822(\sqrt{0,687})$, kepuasan sebesar 0,818 sebesar $(\sqrt{0,669})$, niat beli sebesar 0,763 sebesar $(\sqrt{0,582})$ dan kenikmatan sebesar 1,00 
$(\sqrt{1,00})$. Dari tabel di atas dapat disimpulkan bahwa konstruk kenikmatan memiliki nilai lebih besar daripada konstruk lainya yaitu kelanjutan pembelian, kepercayaan, kepuasan, manfaat sosial, manfaat ekonomi, dan niat beli. Hal ini menunjukkan bahwa seluruh konstruk memiliki discriminant validity yang baik dan memenuhi kriteria discriminant validity.

C. Composite Reliability

Konstruk dinyatan reliabel jika memiliki composite reliability $>06$. Hasil dari composite reliability dapat dilihat pada tabel 3 .

Tabel 3.Composite Reliability

\begin{tabular}{l|r}
\hline & \multicolumn{1}{|c}{ Composite Reliability } \\
\hline KP1 & 0,771 \\
\hline KPS1 & 0,799 \\
\hline MS1 & 0,812 \\
\hline ME1 & 0,736 \\
\hline KN1 & 1,000 \\
\hline KL & 0,814 \\
\hline NB & 0,733 \\
\hline
\end{tabular}

Pada tabel 3. model menunjukkan nilai composite reliability untuk semua konstruk $>0,6$, maka disimpulkan bahwa semua instrumen penelitian ini valid karena semua konstruk memiliki nilai di atas syarat minimum.

D. Cronbach's Alpha

Konstruk dinyatakan reliabel jika nilai cronbach's alpha >0,6. Hasil dari cornbach's Alpha dapat dilihat pada table 4.

Tabel 4. Cronbach's Alpha

\begin{tabular}{l|r}
\hline & \multicolumn{2}{|c}{ Cronbach's Alpha } \\
\hline KP1 & 0447 \\
\hline KPS1 & 0,531 \\
\hline MS1 & 0,545 \\
\hline ME1 & 0,464 \\
\hline KN1 & 1,00 \\
\hline KL & 0,551 \\
\hline NB & 0,291 \\
\hline
\end{tabular}

Berdasarkan tabel 4. disimpulkan bahwa variabel kenikmatan dengan nilai 1,00 merupakan nilai Cronbach's Alpha tertinggi dan variabel niat beli dengan nilai 0,291 adalah yang terendah.

\subsection{Pengujian Structural (Inner) Model}

Model struktural mencakup pengujian determinasi atau reliabilitas indikator $\left(r^{2}\right)$ dan nilai t-statistik dari pengujian koefisien jalur (path coefficient) yang merupakan uji good-fit model. A. Uji Determinasi atau Analisis Varians $\left(r^{2}\right)$

Uji Varian $\left(\mathrm{r}^{2}\right)$ dilakukan untuk mengetahui seberapa besar kontribusi variabel kepercayaan, manfaat sosial, manfaat ekonomi, kenikmatan, kelanjutan pembelian, kepuasan dan niat. Hasil dari pengujian varians $\left(\mathrm{r}^{2}\right)$ ditunjukkan pada tabel 5. 
Tabel 5. Nilai $\mathrm{r}^{2}$

\begin{tabular}{|l|r|r|}
\hline & R Square & R Square Adjusted \\
\hline Kepuasan & 0,161 & 0,116 \\
\hline Niat Beli & 0,319 & 0,275 \\
\hline
\end{tabular}

Dari tabel 5. model pengaruh kepercayaan, manfaat sosial, manfaat ekonomi, kenikmatan, kelanjutan pembelian terhadap kepuasan memberikan nilai R-square sebesar 0,161 yang dapat diinterpretasikan bahwa masing-masing variabelitas terhadap konstruk kepuasan sebesar 16,1 \% sedangkan 83,9 dijelaskan oleh variabel di luar penelitian. Model pengaruh kepercayaan, manfaat sosial, manfaat ekonomi, kenikmatan, kelanjutan pembelian, kepuasan terhadap niat beli memberikan nilai R-square sebesar 0,319 yang dapat diinterpretasikan bahwa masing-masing variabelitas terhadap konstruk niat beli sebesar 31,9 \% sedangkan 68,1 dijelaskan oleh variabel di luar penelitian.

B. Pengujian Hipotesis

Menurut [28] ukuran signifikansi keterdukungan hipotesis dapat digunakan perbandingan nilai $T$-table dan $T$-statistic. Hasil uji hipotesis penelitian dapat dilihat dalam table 6 .

Tabel 6. Tabel Path Coefficient

\begin{tabular}{|c|c|c|c|c|c|}
\hline & $\begin{array}{c}\text { Beta } \\
(\beta)\end{array}$ & $\begin{array}{c}\text { Sampel } \\
\text { Mean (M) }\end{array}$ & $\begin{array}{c}\text { Standard Deviation } \\
\text { (STDEV) }\end{array}$ & T_Statistik & $\begin{array}{c}\mathbf{P} \\
\text { Values }\end{array}$ \\
\hline KP1 ‥-> KPS1 & 0,140 & 0,132 & 0,188 & 0,749 & 0,454 \\
\hline$K P I \ldots>N B I$ & 0,011 & 0,036 & 0,150 & 0,074 & 0,941 \\
\hline$M S I \ldots>$ KPSI & 0,111 & 0,104 & 0,111 & 1,002 & 0,317 \\
\hline$M S 1 \ldots>N B 1$ & 0,096 & 0,099 & 0,106 & 0,906 & 0,366 \\
\hline ME1 $1 \ldots$ KPS1 & $-0,036$ & $-0,012$ & 0,142 & 0,252 & 0,801 \\
\hline ME1 …> NB1 & 0,288 & 0,293 & 0,102 & 2,834 & 0,005 \\
\hline KN1 …> KPS1 & 0,086 & 0,088 & 0,167 & 0,513 & 0,608 \\
\hline $\mathrm{KN} 1 \ldots \mathrm{NB} 1$ & 0,076 & 0,059 & 0,090 & 0,841 & 0,401 \\
\hline KL1 …> KPS1 & 0,246 & 0,251 & 0,119 & 2,071 & 0,039 \\
\hline KL1 …> NB1 & 0,238 & 0,237 & 0,109 & 2,181 & 0,030 \\
\hline KPS1 …> NB1 & 0,081 & 0,099 & 0,106 & 0,768 & 0,443 \\
\hline
\end{tabular}

Dari tabel 6 di atas menyimpulkan bahwa kepercayaan tidak signifikan terhadap kepuasan (T-statistik=0,749) dan niat beli (T-statistik= 0,074) dengan demikian H1a dan H1b tidak didukung. Manfaat sosial dalam kontek belanja daring P2P melalui media sosial tidak signifikan terhadap kepuasan $(\mathrm{T}$-statistik $=1,002)$ dan niat beli $(\mathrm{T}$-statistik=0,906) dengan demikian $\mathrm{H} 2 \mathrm{a}$ dan $\mathrm{H} 2 \mathrm{~b}$ tidak didukung. Manfaat ekonomi tidak signifikan terhadap kepuasan (T-statistik= 0,252) namun memiliki pengaruh positif terhadap niat beli $(\mathrm{T}$-statistik= 2,834) sehingga $\mathrm{H} 3 \mathrm{a}$ tidak didukung dan $\mathrm{H} 3 \mathrm{~b}$ didukung. Kenikmatan tidak signifikan terhadap kepuasan ( $\mathrm{T}$-statistik=0,513) dan niat beli $(\mathrm{T}$-statistik= 0,841) sehingga $\mathrm{H} 4 \mathrm{a}$ dan $\mathrm{H} 4 \mathrm{~b}$ tidak didukung. Kelanjutan pembelian memiliki pengaruh terhadap kepuasan $(\mathrm{T}$-statistik= 2,071) dan niat beli (T-statistik=2,181) sehingga H5a dan H5b didukung. H6 dalam penelitian ini tidak didukung karena kepuasan pelanggan tidak berpengaruh positif terhadap niat bali (Tstatistik=0,768).

\section{Kesimpulan}

Studi ini menyimpulkan bahwa faktor-faktor penentu niat beli konsumen pada konteks akomodasi P2P yang dilakukan [21] dan transportasi daring P2P yang dilakukan [22] dapat diterapkan pada konteks industry lainnya seperti konteks belanja daring P2P melalui media 
sosial Facebok dan Instagram meskipun terdapat perbedaan. Pada penelitian ini manfaat ekonomi tidak signifikan terhadap kepuasan namun memiliki pengaruh positif terhadap niat beli. Kelanjutan pembelian memiliki pengaruh terhadap kepuasan dan niat beli.

Saran untuk penelitian selanjutnya untuk meneliti di layanan Peer-to-Peer lainnya yang menggunakan bisnis lain dari berbagi ekonomi dan mengkonfirmasi kembali model penelitian ini pada kontek e-commerce lainnya, misalnya pada layanan keuangan dan crowdfunding. Pada penelitian selanjutnya dapat dilakukan dengan ukuran sampel yang lebih besar dan software yang berbeda sehingga penelitian ini tidak hanya diterapkan menggunakan model SEM-PLS sehingga dapat menghasilkan analisis data yang lebih dapat diandalkan, lebih besar dan variabel tersebut tergolong kuat.

\section{Daftar Pustaka}

[1] Azar, S. et al. (2015). Familiarity with Online retailing Special Issue on Sydney Conference Held in April 2015. The Journal of Developing Areas, 49(6), 133-144.

[2] Botsman, R., \& Rogers, R. (2010). What's mine is yours - the rise of collaborative consumption. HarperCollins: NY.

[3] Ghozali, I. (2005). Aplikasi Analisis Multivariate dengan SPSS. Semarang: Badan Penerbit UNDIP.

[4] Ghozali, I. (2009). “Aplikasi Analisis Multivariate dengan Program SPSS “. Semarang: UNDIP.

[5] Ghozali, I., \& Latan, H. (2015). Partial Least Squares Konsep, Teknik dan Aplikasi Menggunakan Program SmartPLS 3.0 Untuk Penelitian Empiris.Edisi 2. UNDIP.

[6] Glind, P. van de. (2013). The consumer potential of Collaborative Consumption. Research MSc in Sustainable Development - Environmental Governance, 1-65.

[7] Hair, J. F., Tatham, R. L., Anderson, R. E., \& Black, W. (1998). Multivariate Data Analysis (5th Edition) (Upper Sadd). Prentice Hall.

[8] Hamari, J., Sjöklint, M., \& Ukkonen, A. (2015). The Sharing Economy: Why People Participate in Collaborative Consumption. Journal Of The Association For Information Science And Technology, 59(1), 126-135. https://doi.org/10.1002/asi

[9] Hill, W. W., \& Beatty, S. E. (2011). A model of adolescents' online consumer selfefficacy (OCSE). Journal of Business Research, 64(10), 1025-1033. https://doi.org/10.1016/j.jbusres.2010.11.008

[10] Ingham, J. et al. (2015). E-Shopping acceptance: A qualitative and meta-analytic review. Information and Management, 52(1), 44-60. https://doi.org/10.1016/j.im.2014.10.002

[11] Irani, N., \& Hanzaee, K. H. (2011). The Effects of Variety-seeking Buying Tendency and Price Sensitivity on Utilitarian and Hedonic Value in Apparel Shopping Satisfaction. International Journal of Marketing Studies, 3(3). https://doi.org/10.5539/ijms.v3n3p89

[12] James, P. (2015). Urban sustainbility in theory and practice. New York: British Library Library of Congress.

[13] Jogiyanto, \& Abdillah, W. (2009). Konsep dan Aplikasi PLS (Partial Least Square) Untuk Penelitian Empiris. Yogyakarta: Badan Penerbit Fakultas Ekonomi.

[14] Juju, D. (2010). Cara mudah buka toko online dengan Wordpress + WP E-Commerce. Yogyakarta: CV Andi Offset.

[15] Kaplan, A. M., \& Haenlein, M. (2010). Users of the world, unite! The challenges and opportunities of Social Media. Business Horizons, 53(1), 59-68. https://doi.org/10.1016/j.bushor.2009.09.003 
[16] Kuntjara. (2007). Analisis Faktor-Faktor Yang Mempengaruhi Minat Beli Ulang Konsumen (Studi Kasus di PT Wijaya Beton Wilayah IV; Jateng, DIY, Kalsel dan Kalteng. Tesis.

[17] Laudon. (2003). Management information systems: managing the digital firm. Revista de Administração Contemporânea (Vol. 7). https://doi.org/10.1590/S141565552003000100014

[18] Lee, M. K. O., \& Turban, E. (2001). A trust model for consumer internet shopping. International Journal of Electronic Commerce, 6(1), 75-91. https://doi.org/10.1080/10864415.2001.11044227

[19] Möhlmann, M. (2015). Collaborative consumption: determinants of satisfaction and the likelihood of using a sharing economy option again. Journal of Consumer Behaviour, 14, 193-207. https://doi.org/10.1002/cb

[20] Palvia, P. (2009). The role of trust in e-commerce relational exchange: A unified model. $\begin{array}{lll}\text { Information and } & \text { 46(4), }\end{array}$ https://doi.org/10.1016/j.im.2009.02.003

[21] Pavlou. (2003). Consumer Acceptance of Electronic Commerce: Integrating Trust and Risk with the Technology Acceptance Model. International Journal of Electronic Commerce, 7(3), 101-134. https://doi.org/10.1080/10864415.2003.11044275

[22] Santoso, A. S., \& Nelloh, L. A. M. (2017). User Satisfaction and Intention to Use Peerto-Peer Online Transportation: A Replication Study. Procedia Computer Science, 124, 379-387. https://doi.org/10.1016/j.procs.2017.12.168

[23] Sugiyono. (2016). Metode Penelitian Kuantitatif, Kualitatif dan R\&D. Bandung: PT Alfabet.

[24] Sukma, A. A. (2012). Analisis faktor-faktor yang mempengaruhi keputusan pembelian social networking websites. Jurnal Ekonomi Manajemen, 2(1), 1-11. https://doi.org/10.1016/j.ntt.2007.12.005

[25] Sundararajan, A. (2016). The Sharing Economy: The End of Employment and the Rise of Crowd-Based Capitalism - Book Reviews - IMF FINANCE \& DEVELOPMENT June 2016 • Volume 53• Number 2, 256(June), 2016.

[26] Tussyadiah, I. P. (2016). Factors of satisfaction and intention to use peer-to-peer accommodation. International Journal of Hospitality Management, 55, 70-80. https://doi.org/10.1016/j.ijhm.2016.03.005

[27] Wallace, E., Buil, I., Chernatony, L. de, \& Hogan, M. (2014). Who "Likes" You ... and Why? A Typology of Facebook Fans. Journal of Advertising Research, 54(1), 92-109. https://doi.org/10.2501/jar-54-1-092-109

[28] Wicaksono, Y. (2008). Membangun Bisnis Online dg Mambo++ CD. Jakarta: PT. Elex Media Komputindo. 